\title{
The hydrochemistry of rivers in KwaZulu-Natal
}

\author{
Stephanie de Villiers \\ Department of Chemistry, University of Stellenbosch, Stellenbosch 7602, South Africa
}

\begin{abstract}
The chemistry of the major elements of KwaZulu-Natal river water draining the eastern Drakensberg Escarpment was monitored in October 2003 and compared to data obtained previously along the western Drakensberg Escarpment, i.e. the Caledon and Upper Orange Rivers. The data obtained in these two surveys reveal no significant differences in the $\mathrm{Mg}, \mathrm{Ca}, \mathrm{Na}, \mathrm{K}$ and $\mathrm{HCO}_{3}$ - content of rivers draining similar lithologies, despite slightly different climatic regimes and different suspended loads. The implication is that lithology is the dominant control on the major element chemistry of river water draining the Drakensberg. However, in the north-western part of KwaZulu-Natal, drought-stricken at the time of sampling, evaporation-induced concentration results not only in evaporite formation, but dramatic changes in river and stream water chemistry. Elevated levels of minor constituents such as $\mathrm{NO}_{3}^{-}$also indicate that in cultivated areas anthropogenic activities have an impact on water quality and composition.
\end{abstract}

Keywords: KwaZulu-Natal, hydrochemistry, river water, Drakensberg, lithology

\section{Introduction}

The chemistry of unpolluted freshwater systems such as rivers is primarily controlled by the lithology of the drainage basin and weathering stoichiometry (Meybeck, 1987; Dupré et al., 2003). Changing land-use patterns in Southern Africa, together with climate change, will almost certainly impact on erosion rates and chemical weathering processes, with important implications for river suspended and dissolved loads (Legesse et al., 2003). Southern Africa in general and the high-relief and erodable sedimentary layers of the Drakensberg Escarpment in particular, are extremely susceptible to such change (Keulder, 1979). Its impact on the quality of freshwater, our most valuable natural resource, can only be assessed and reliably predicted if the fundamental controls on river water chemistry are understood (Day and King, 1995; Scharler and Baird, 2003).

A study of the correspondence between river water strontium isotope $\left({ }^{87} \mathrm{Sr} /{ }^{86} \mathrm{Sr}\right)$ composition and dominant drainage basin lithology in the Orange-Caledon-Vaal River system (De Villiers et al., 2000), demonstrated the extent to which river water chemistry is controlled by lithology. This study investigates whether the relationship between river water chemistry and lithology demonstrated for rivers draining the western Drakensberg Escarpment, i.e. the Caledon and Upper Orange Rivers, holds along the eastern Drakensberg Escarpment. Most of the rivers sampled in KwaZulu-Natal drain rocks of the Karoo Supergroup, i.e. the same lithological provinces as the Caledon and Upper Orange Rivers. Given that catchments along the eastern Drakensberg Escarpment experience higher average annual rainfall than along the western escarpment, this study also provides an evaluation of the possible secondary role of climate on chemical weathering processes and river chemistry. River water runoff provides most of the freshwater used for human, agricul-

\footnotetext{
* To whom all correspondence should be addressed.

甶 +2721 808-2732; fax: +2721 808-3849;

e-mail: steph@sun.ac.za

Received 9 September 2004; accepted in revised form 14 January 2005.
}

tural and industrial utilisation in KwaZulu-Natal, and the results are therefore also of direct relevance to the assessment of water quality for these purposes (DWAF, 1996; Lin et al., 2004).

\section{Geology of the catchment area}

The basal Karoo sequence consists of the Dwyka Formation (tillite-dominated), overlain by the carbonaceous shale, dolomite, mudstone, siltstone and organic-rich layers of the Ecca Group (Smith, 1990; Johnson et al., 1996). Above this is the Permian-Triassic Beaufort Group (alternating calcareous and noncalcareous mudstone), including the coarse sandstone- dominated Upper Triassic Molteno Formation. This is followed by the Elliot and Clarens Formations (fine-grained red beds and yellow sandstone) which in turn are capped by the Drakensberg Group (Jurassic flood basalt). The rivers originating in the easternmost part of KwaZulu-Natal drain primarily rocks of the Natal Group and Natal metamorphic belt.

\section{Climate and geography of the catchment area}

Rainfall in KwaZulu-Natal is strongly seasonal with more than $80 \%$ falling between October and March (WRC, 2002). This sampling survey was conducted during October, i.e. before the rainy season and additionally, towards the end of one of the most severe droughts on record in the north-western part of KwaZuluNatal.

In the west, i.e. the vicinity of the Drakensberg Mountain, the terrain varies from high mountains (average altitude of $1600 \mathrm{~m}$ ) to undulating hills and lowlands (WRC, 2002). Soils are mostly well-drained. The average air temperature is $15^{\circ} \mathrm{C}$, mean annual precipitation (MAP) $720 \mathrm{~mm}$ and mean annual runoff (MAR) $195 \mathrm{~mm}$ (WRC, 2002). Towards the east the terrain becomes a mix of highly dissected low mountains and lowlands (average altitude $650 \mathrm{~m}$ ). The average air temperature is $18^{\circ} \mathrm{C}$, MAP $890 \mathrm{~mm}$ and MAR $100 \mathrm{~mm}$. Soils here consist of a greater proportion of shallow and poorly drained soils. Along the coastal plains the average altitude is $<200 \mathrm{~m}$ and the soils consist predominantly of shallow soils on well-weathered rock. 


\begin{tabular}{|c|c|c|c|c|}
\hline \multicolumn{5}{|c|}{$\begin{array}{c}\text { TABLE 1 } \\
\text { River water sampling locations in KwaZulu-Natal }\end{array}$} \\
\hline Sample & River name & Latitude & $\begin{array}{l}\text { Longi- } \\
\text { tude }\end{array}$ & Dominant Formation/Group \\
\hline$\overline{\mathrm{KZN} \_1}$ & Elands River & $29^{\circ} 40^{\prime} \mathrm{S}$ & $30^{\circ} 04^{\prime} \mathrm{E}$ & Drakensberg \\
\hline KZN_2 & Mkomazi River & $29^{\circ} 45^{\prime} \mathrm{S}$ & $29^{\circ} 50^{\prime} \mathrm{E}$ & Drakensberg, Molteno, Elliot, Clarens \& Beaufort \\
\hline KZN_3 & Mzimkhulu River & $29^{\circ} 46^{\prime} \mathrm{S}$ & $29^{\circ} 29^{\prime} \mathrm{E}$ & Drakensberg, Molteno, Elliot, Clarens \& Beaufort \\
\hline KZN_4 & Pholela River & $29^{\circ} 56^{\prime} \mathrm{S}$ & $29^{\circ} 31^{\prime} \mathrm{E}$ & Drakensberg, Molteno, Elliot, Clarens \& Beaufort \\
\hline KZN_5 & Mkhomazana River & $29^{\circ} 39^{\prime} \mathrm{S}$ & $29^{\circ} 32^{\prime} \mathrm{E}$ & Drakensberg, Molteno, Elliot, Clarens \& Beaufort \\
\hline KZN_6 & Umkomaas River & $29^{\circ} 36^{\prime} \mathrm{S}$ & $29^{\circ} 33^{\prime} \mathrm{E}$ & Drakensberg, Molteno, Elliot, Clarens \& Beaufort \\
\hline KZN_7 & Nhlathimbe River & $29^{\circ} 33^{\prime} \mathrm{S}$ & $29^{\circ} 34^{\prime} \mathrm{E}$ & Drakensberg, Molteno, Elliot, Clarens \& Beaufort \\
\hline$\overline{\mathrm{KZN} \_8}$ & Nzinga River & $29^{\circ} 28^{\prime} \mathrm{S}$ & $29^{\circ} 55^{\prime} \mathrm{E}$ & Molteno, Elliot, Clarens \& Beaufort \\
\hline KZN_9 & Mooi River & $29^{\circ} 14^{\prime} \mathrm{S}$ & $30^{\circ} 00^{\prime} \mathrm{E}$ & Molteno, Elliot, Clarens \& Beaufort \\
\hline KZN_10 & Bushmans River & $29^{\circ} 01^{\prime} \mathrm{S}$ & $29^{\circ} 55^{\prime} \mathrm{E}$ & Molteno, Elliot, Clarens \& Beaufort \\
\hline KZN_11 & Tugela River & $28^{\circ} 45^{\prime} \mathrm{S}$ & $29^{\circ} 25^{\prime} \mathrm{E}$ & Drakensberg, Molteno, Elliot, Clarens \& Beaufort \\
\hline KZN_12 & Tugela River trib & $28^{\circ} 37^{\prime} \mathrm{S}$ & $29^{\circ} 05^{\prime} \mathrm{E}$ & Drakensberg, Molteno, Elliot, Clarens \& Beaufort \\
\hline KZN_13 & Klip River & $28^{\circ} 34^{\prime} \mathrm{S}$ & $29^{\circ} 44^{\prime} \mathrm{E}$ & Beaufort \\
\hline KZN_14 & Busi River & $28^{\circ} 15^{\prime} \mathrm{S}$ & $30^{\circ} 06^{\prime} \mathrm{E}$ & Beaufort \\
\hline KZN_15 & Blood River & $27^{\circ} 50^{\prime} \mathrm{S}$ & $30^{\circ} 35^{\prime} \mathrm{E}$ & Dwyka \& Ecca \\
\hline KZN_16 & Mkuzi River & $27^{\circ} 40^{\prime} \mathrm{S}$ & $31^{\circ} 30^{\prime} \mathrm{E}$ & Dwyka, Ecca, Natal and Pongola \\
\hline KZN_17 & Pongola River & $27^{\circ} 28^{\prime} \mathrm{S}$ & $31^{\circ} 35^{\prime} \mathrm{E}$ & Dwyka, Ecca, Natal and Pongola \\
\hline KZN_18 & Mkuzi Village pump & $27^{\circ} 41^{\prime} \mathrm{S}$ & $32^{\circ} 08^{\prime} \mathrm{E}$ & Natal Group/metamorphic belt/Pongola Supergroup \\
\hline KZN_19 & Mkuzi GR tap water & $27^{\circ} 41^{\prime} \mathrm{S}$ & $32^{\circ} 09^{\prime} \mathrm{E}$ & Natal Group/metamorphic belt/Pongola Supergroup \\
\hline KZN_21 & Mfolozi River & $28^{\circ} 29^{\prime} \mathrm{S}$ & $32^{\circ} 11^{\prime} \mathrm{E}$ & Natal Group/metamorphic belt/Pongola Supergroup \\
\hline KZN_22 & Mhlatuze River & $28^{\circ} 46^{\prime} \mathrm{S}$ & $31^{\circ} 59^{\prime} \mathrm{E}$ & Natal Group/metamorphic belt/Pongola Supergroup \\
\hline
\end{tabular}

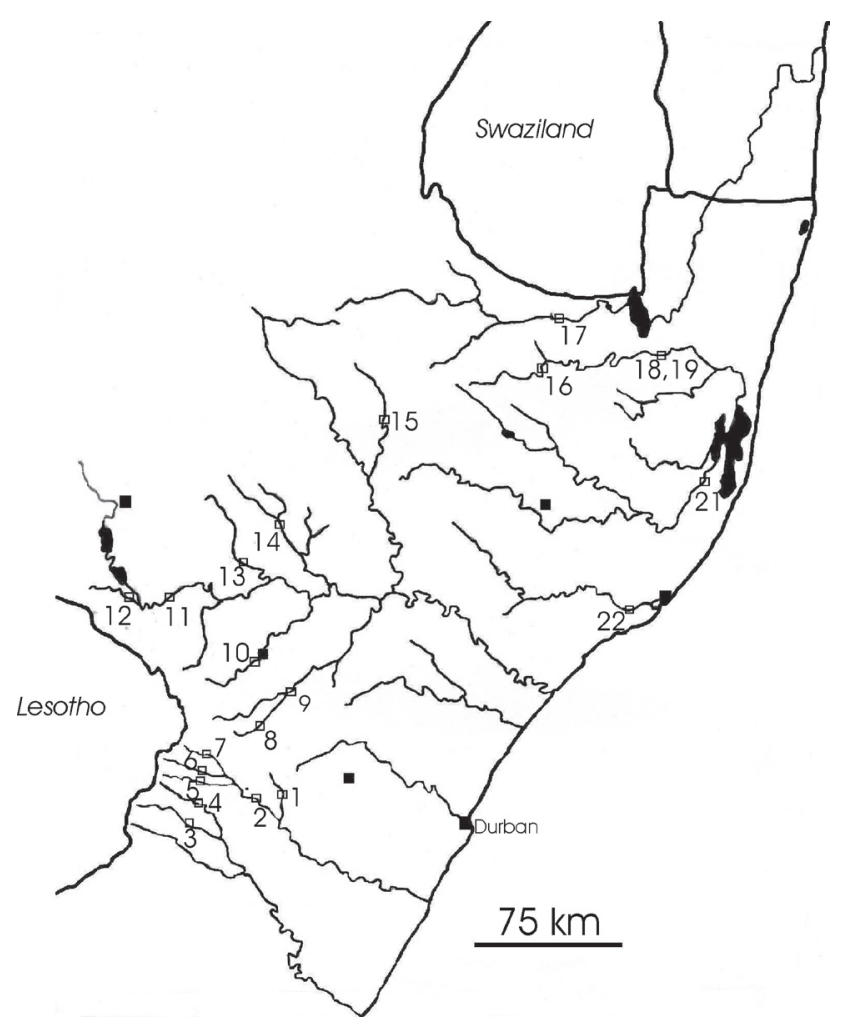

Figure 1

Map of KwaZulu-Natal sampling stations
The average air temperature is $20^{\circ} \mathrm{C}$; MAP is $890 \mathrm{~mm}$ and MAR $120 \mathrm{~mm}$.

\section{Sampling and analytical methods}

Sampling locations and ancillary information are listed in Table 1 and shown in Fig. 1. Samples KZN1 to KZN12 in western KwaZulu-Natal drain rocks and sediments belonging to the Karoo Supergroup, as do KZN13 to KZN15 in the north-western part of the province. Samples KZN16 to KZN22 drain Karoo sediments as well as lithologies belonging to the Natal Group and Natal Metamorphic Belt, i.e. a complicated mixture of different rock types.

All of the samples contained very low levels of suspended material, estimated at below $20 \mathrm{mg} / \ell$ for all samples. The low total suspended (TSS) content of the samples can probably be ascribed to the dry/drought and low-flow conditions during the time of sampling.

Water samples were collected in high-density polyethylene sampling bottles. Within $12 \mathrm{~h}$ after collection the samples were filtered through $0.45 \mu \mathrm{m}$ filters, a fraction acidified and kept for trace metal analysis, and $\mathrm{pH}$, conductivity and alkalinity measurements performed on a non-acidified fraction. Back in the laboratory (within a week after sampling) analysis of major cation and anion analyses was carried out using a DIONEX ICS90 single-channel ion chromatograph. The certified reference material ION-20 (medium-hard lake water) was analysed to evaluate analytical accuracy, which was within 2 to $5 \%$ for all components reported. 


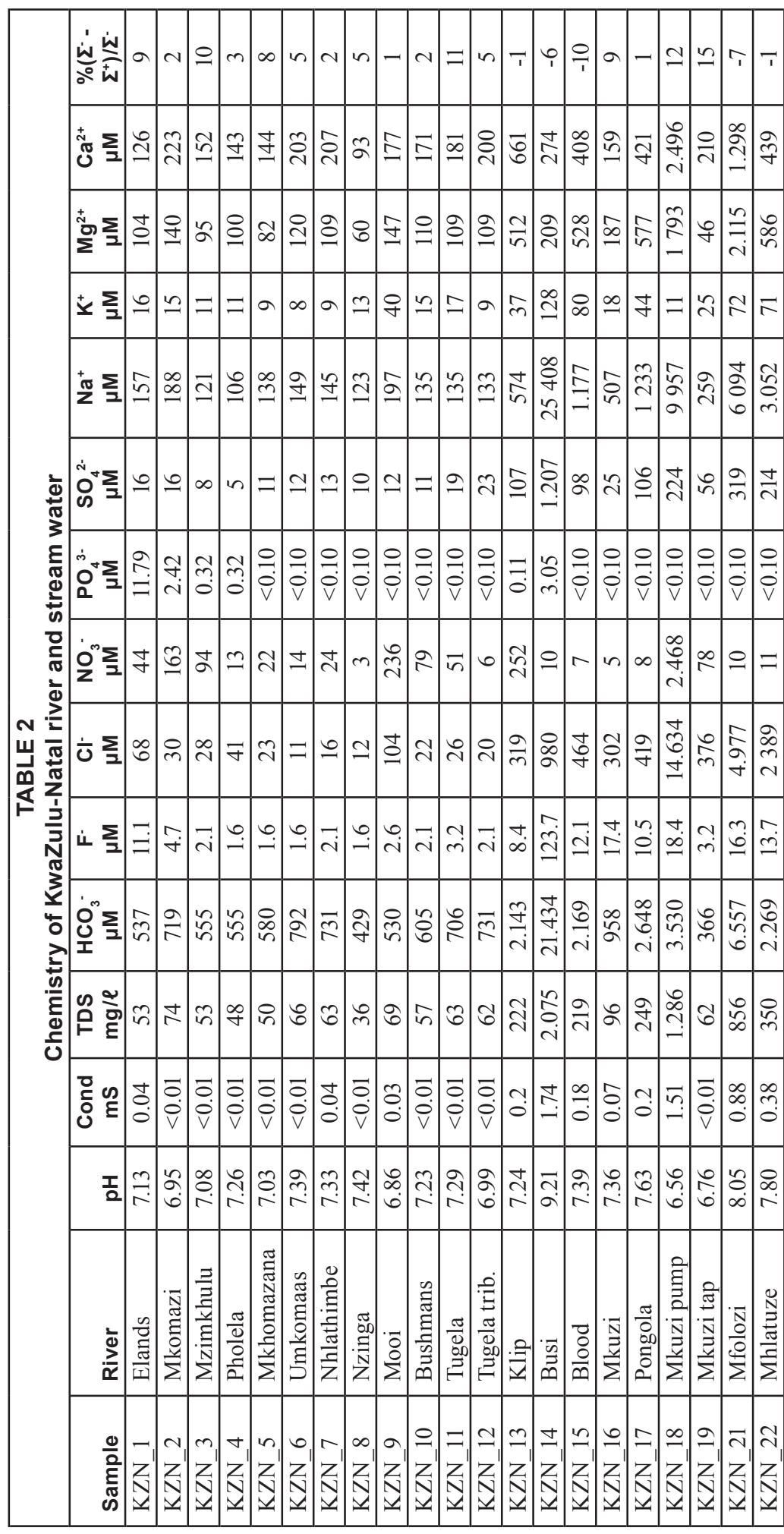

\section{Results and discussion}

\section{Hydrochemistry}

The hydrochemistry results are summarised in Table 2. Conductivity is low $(<0.1 \mathrm{mS})$ in surface water draining Karoo Supergroup lithologies, with the exception of the rivers in the north-western part of KwaZulu-Natal (KZN13 to KZN17) and those draining the coastal belt (KZN18 to KZN22). The same trend is observed for the total dissolved solid (TDS) content of surface waters. TDS values of 219 to $2075 \mathrm{mg} / \ell$ were observed in the north-west (KZN13 to KZN15), where severe drought conditions prevailed during the time of sampling. High TDS values also characterise surface water along the coastal belt (KZN18 to 22).

Sodium, $\mathrm{Mg}$ and $\mathrm{Ca}$ are the dominant cations in all the water samples analyzed, with $\mathrm{HCO}_{3}{ }^{-} \mathrm{Cl}^{-}$and $\mathrm{SO}_{4}^{-2}$ providing the charge balance (Table 2). In western KwaZulu-Natal river waters draining Karoo lithologies contain almost equivalent amounts of $\mathrm{Na}$ and $\mathrm{Ca}$ (35 to $40 \%$ of each) with Mg only slightly less abundant. This is similar to what is observed for rivers draining western Drakensberg Karoo sequences (De Villiers et al., 2000). Sodium, however, is the dominant cation in the droughtstricken north-western part of the province and along the coastal belt, by a factor of two in most cases (Table 2, KZN13 to KZN22). Bicarbonate is the dominant anion in all waters draining Karoo Supergroup lithologies. Along the coastal belt, however, $\mathrm{HCO}_{3}^{-}$and $\mathrm{Cl}^{-}$concentrations are equivalent, and $\mathrm{Cl}^{-}$is the dominant anion in the Mkuzi Village pump (ground) water sample (Table 2).

\section{Ionic ratios}

The ion ratios (mole/mole) for $\mathrm{Mg}, \mathrm{Ca}, \mathrm{Na}$ and $\mathrm{K}$ are listed in Table 3. In western KwaZuluNatal $\mathrm{N}$ and $\mathrm{Ca}$ are present in approximately equivalent concentrations, followed closely by $\mathrm{Mg}$. Average values for the cation ratios in water draining the eastern Drakensberg Escarpment are almost identical to those measured in Orange and Caledon River waters that drain the western Drakensberg escarpment (Table 3; De Villiers et al., 2000). Superimposed upon these relative cation abundance values, are definitive trends in $\mathrm{Mg} / \mathrm{K}$ and $\mathrm{Ca} / \mathrm{K}$ values (Fig. 2). High $\mathrm{Mg} / \mathrm{K}$ and $\mathrm{Ca} / \mathrm{K}$ values $(>25$ ) reflect the $\mathrm{Mg}$ - and $\mathrm{Ca}$-rich composition of basalt and dolerite (Keulder, 1979), in contrast to the more K-rich sand- and mudstones of the Karoo Supergroup sedimentary sequences (Keulder, 1979). The highest $\mathrm{Mg} / \mathrm{K}$ and $\mathrm{Ca} / \mathrm{K}$ values found are those of KZN6, 7 and 12, i.e. the sampling sites closest to the central and northern Drakensberg area. The lowest $\mathrm{Mg} / \mathrm{K}$ and $\mathrm{Ca} / \mathrm{K}$, in contrast, are those of $\mathrm{KZN} 1,8$ and 9 , i.e. the sampling sites that originate within the Karoo sedimentary sequences well below the Drakensberg basalt sequence. Since Drakensberg basalt is found only above an altitude of approximately $1800 \mathrm{~m}$ along the escarpment, the results suggest that $\mathrm{Mg} / \mathrm{K}$ and $\mathrm{Ca} / \mathrm{K}$ can be used as indicators of the relative altitude from which river water along the escarpment was sourced. However, the presence of dolerite dykes, compositionally similar to Drakensberg basalt, at lower altitude may complicate the use of these ratios as source indicators.

The chemical composition of river water in 


\begin{tabular}{|c|c|c|c|c|}
\hline \multicolumn{5}{|c|}{$\begin{array}{c}\text { TABLE } 3 \\
\text { Cation ratios (mole fraction) in KwaZulu-Natal } \\
\text { river water samples }\end{array}$} \\
\hline Sample & $\mathrm{Mg}$ & $\mathrm{Ca}$ & $\mathrm{Na}$ & $\mathrm{K}$ \\
\hline KZN_1 & 0.26 & 0.31 & 0.39 & 0.04 \\
\hline KZN 2 & 0.25 & 0.39 & 0.33 & 0.03 \\
\hline KZN_3 & 0.25 & 0.40 & 0.32 & 0.03 \\
\hline KZN_4 & 0.28 & 0.40 & 0.29 & 0.03 \\
\hline KZN_5 & 0.22 & 0.39 & 0.37 & 0.02 \\
\hline KZN_6 & 0.25 & 0.42 & 0.31 & 0.02 \\
\hline KZN_7 & 0.23 & 0.44 & 0.31 & 0.02 \\
\hline KZN_8 & 0.21 & 0.32 & 0.43 & 0.05 \\
\hline KZN_9 & 0.26 & 0.32 & 0.35 & 0.07 \\
\hline KZN 10 & 0.26 & 0.40 & 0.31 & 0.04 \\
\hline KZN_11 & 0.25 & 0.41 & 0.31 & 0.04 \\
\hline KZN 12 & 0.24 & 0.44 & 0.30 & 0.02 \\
\hline KZN_13 & 0.29 & 0.37 & 0.32 & 0.02 \\
\hline KZN_14 & 0.01 & 0.01 & 0.98 & 0.00 \\
\hline KZN_15 & 0.24 & 0.19 & 0.54 & 0.04 \\
\hline KZN 16 & 0.21 & 0.18 & 0.58 & 0.02 \\
\hline KZN_17 & 0.25 & 0.19 & 0.54 & 0.02 \\
\hline KZN_18 & 0.13 & 0.18 & 0.70 & 0.00 \\
\hline KZN_19 & 0.08 & 0.39 & 0.48 & 0.05 \\
\hline KZN_21 & 0.22 & 0.14 & 0.64 & 0.01 \\
\hline KZN_22 & 0.14 & 0.11 & 0.74 & 0.02 \\
\hline $\begin{array}{l}\text { KZN-W } \\
\text { avg. }\end{array}$ & 0.25 & 0.39 & 0.33 & 0.03 \\
\hline $\begin{array}{l}\text { KZN- } \\
\text { NW avg. }\end{array}$ & 0.18 & 0.19 & 0.61 & 0.02 \\
\hline $\begin{array}{l}\text { KZN- } \\
\text { coast avg. }\end{array}$ & 0.17 & 0.20 & 0.61 & 0.02 \\
\hline $\begin{array}{l}\text { Upper } \\
\text { Orange } \\
\text { avg. }\end{array}$ & 0.26 & 0.35 & 0.35 & 0.04 \\
\hline
\end{tabular}

the drought-stricken north-western part of KZN suggests that evaporation-induced concentration results in relatively lower calcium and $\mathrm{Mg}$ levels, with $\mathrm{Na}$ becoming the dominant cation (Table 3). These ion ratio changes together with high dissolved ion concentrations imply the formation of $\mathrm{Ca}$ and $\mathrm{Mg}$ evaporite mineral phases. Calcium and $\mathrm{Mg}$ carbonates are typically precipitated out first during evaporite formation from natural water bodies (Harvie et al., 1984). The high solute content of KZN14 (Table 2) suggests that super-saturation with respect to $\mathrm{Ca}$ (and $\mathrm{Mg}$ ) carbonate mineral phases has been reached, i.e. that evaporite mineral formation has commenced. Along the coastal belt, $\mathrm{Na}$ becomes the dominant cation (Table 2). The dissolution of soluble $\mathrm{Na}$ mineral phases of seawater intrusion along the coastal belt is also suggested by elevated $\mathrm{Cl}^{-}$and $\mathrm{SO}_{4}^{-2}$ levels (Table 2).

\section{Water quality for human consumption}

Target Water Quality Range values for human consumption exist for the following of the chemical species analyzed: $\mathrm{Ca}, \mathrm{Cl}^{-}, \mathrm{F}$, $\mathrm{Mg}, \mathrm{NO}_{3}{ }^{-}$and $\mathrm{N}$ (DWAF, 1996). Several samples exceed one or more of these criteria: $\mathrm{Ca}\left(\mathrm{KZN18}\right.$ and 21), $\mathrm{Cl}^{-}(\mathrm{KZN} 18,21$ and 22), $\mathrm{F}^{-}$(KZN14), $\mathrm{Mg}$ (KZN18 and 21), $\mathrm{NO}_{3}^{-}$(KZN2, 9, 13 and $18)$ and $\mathrm{Na}(\mathrm{KZN} \mathrm{14}, 18$ and 21). There are no potential health

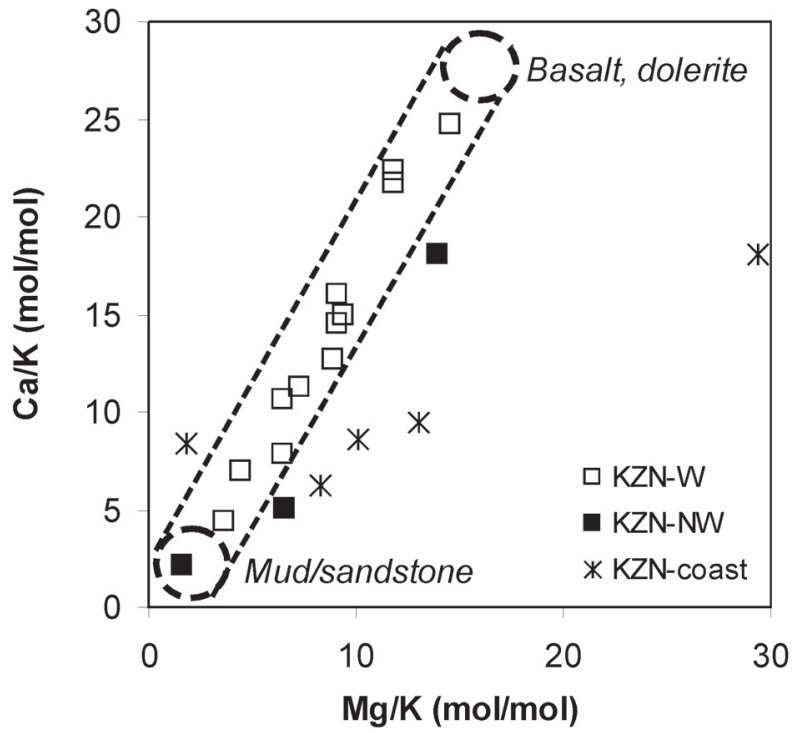

Figure 2

Relationship between $\mathrm{Mg} / \mathrm{K}$ and $\mathrm{Ca} / \mathrm{K}$ of KwaZulu-Natal river water

effects related to the elevated $\mathrm{Ca}, \mathrm{Mg}$ and $\mathrm{Cl}^{-}$levels present, but the levels measured during this sampling survey will result in increased scaling and erosion of, e.g. domestic appliances. Elevated $\mathrm{Na}$ levels can be undesirable for infants or person on a Na-restricted diet, in addition to affecting the taste of the water. The $\mathrm{F}^{-}$levels found at KZN-14 can result in tooth damage and mottling of dental enamel.

The most problematic of the water quality parameters analysed, from a human health perspective, is $\mathrm{NO}_{3}^{-}$. The levels of $\mathrm{NO}_{3}^{-}$found in samples $\mathrm{KZN}-2,9$ and 13 can result in rare instances of methaemoglobinaemia in infants (DWAF, 1996). These sample locations all receive runoff from agricultural areas and fertilisation is the most likely origin of the high $\mathrm{NO}_{3}$ present. Of all the samples analysed the Mkuzi Village pumpwater sample has the highest $\mathrm{NO}_{3}^{-}$levels, $2468 \mu \mathrm{M}$ compared to the $323 \mu \mathrm{M}$ limit above which methaemoglobinaemia occurs in infants, in addition to mucous membrane irritation in adults.

Elevated $\mathrm{PO}_{4}^{3-}$ levels were also found at several locations: KZN1, 2 and 14 the most noticeable. These elevated values do not coincide with that for $\mathrm{NO}_{3}^{-}$, i.e. the presence of agricultural runoff. It more likely reflects usage of stream-water upstream for domestic purposes by rural communities, such as domestic laundry.

\section{Conclusions}

The chemistry of river water draining the western and eastern Drakensberg Escarpment is remarkably similar. This is to be expected on the one hand, given that the rivers drain similar lithologies, but also surprising given the pronounced differences in suspended sediment load during the times of sampling. Equilibrium cation-exchange reactions between dissolved and suspended phases such as clays have been proposed as a potentially important secondary control on river water chemistry. In high turbidity rivers cation-exchange reactions can in fact be the dominant control on river chemistry. Despite the fact that the Orange-Caledon River is the $4^{\text {th }}$ most turbid in the world, the results presented here suggest that cation-exchange reactions do no impact significantly on the major element chemistry of rivers 
draining the Drakensberg.

One of the most promising aspects of the results presented here is that the correspondence between cation ratios and lithology demonstrated along the western Drakensberg Escarpment by de Villiers et al. (2000) holds along the eastern escarpment. Element ratios such as $\mathrm{Mg} / \mathrm{K}, \mathrm{Ca} / \mathrm{K}, \mathrm{Mg} / \mathrm{Na}$ etc. are relatively easy to measure and a much better alternative than time-consuming and expensive ${ }^{87} \mathrm{Sr} /{ }^{86} \mathrm{Sr}$ proxies of water origin. The combined correspondence between lithology and altitude in the Drakensberg provides a relatively easy method by means of which water movement can be traced from different source areas in hydrological studies, in this area.

\section{Acknowledgements}

Funding for this work was provided by the University Research Fund of the (then) University of Natal (now University of KwaZulu-Natal) Durban.

\section{References}

DAY JA and KING JM (1995) Geographical patterns, and their origins, in the dominance of major ions in South African rivers. S. Afr. J. Sci. 91 299-306.

DEPARTMENT OF WATER AFFAIRS AND FORESTRY (DWAF) (1996) South African Water Quality Guidelines: Domestic Water Use ( $2^{\text {nd }}$ edn.). Pretoria. 77-99.

DE VILLIERS S, COMPTON JS and LAVELLE M (2000) The strontium istope systematics of the Orange River, Southern Africa. S. Afr. J. Geol. 103 237-248.
DUPRE B, DESSERT C, OLIVA P, GODDERIS Y, VIERS J, FRANCOIS L, MILLOT R and GAILLARDET J (2003) Rivers, chemical weathering and Earth's climate. CR Geosci. 335 1141-1160.

HARVIE CE, MØLLER N and WEARE JH (1984) The prediction of mineral solubilities in natural waters: the Na-K-Mg-Ca-H-Cl-SO $\mathrm{OH}-\mathrm{HCO}_{3}-\mathrm{CO}_{3}-\mathrm{CO}_{2}-\mathrm{H}_{2} \mathrm{O}$ system to high ionic strengths at $25^{\circ} \mathrm{C}$. Geochim. Cosmochim. Acta 48 723-751.

JOHNSON JR, VAN VUUREN CJ, HEGENBERGER WF, REY R and SHOKO U (1996) Stratigraphy of the Karoo Supergroup in South Africa: An overview. J. Afr. Earth Sci. 23 3-15.

KEULDER PC (1979) Hydrochemistry of the Upper Orange River catchment. J. Limnol. Soc. S. Afr. 5 39-46.

LEGESSE D, VALLET-COULOMB C and GASSE F (2003) Hydrological response of a catchment to climate and land use changes in Tropical Africa: Case study South Central Ethiopia. J. Hydrol. 275 67-85.

LIN J, BIYELA PT, PUCKREE T and BEZUIDENHOUT CC (2004) A study of the water quality of the Mhlathuze River, KwaZuluNatal (RSA): Microbial and physico-chemical factors. Water SA 30 $17-22$.

MEYBECK M (1987) Global chemical weathering from surficial rocks estimated from river dissolved loads. Am. J. Sci. 287 401-428.

SCHARLER UM and BAIRD D (2003) The influence of catchment management on salinity, nutrient stochiometry and phytoplankton biomass of Eastern Cape estuaries, South Africa. Est. Coastal \& Shelf Sci. 56 735-748.

SMITH RHM (1990) A review of stratigraphy and sedimentary environments of the Karoo basin of South Africa. J. Afr. Earth Sci. 10 117-137.

WRC (2002) State-of-Rivers Report. uMngeni and Neighbouring Rivers and Streams. WRC Report No TT 200/02. 
